\title{
THE COMPLEMENT ACTIVITY OF CANINE SERUM
}

\author{
BY N. M. LARIN, RACHEL GADDUM AND W. G. ORBELL \\ Canine Research Station of the Animal Health Trust, \\ Kennett, Nr. Newmarket, Suffolk
}

(With 9 Figures in the Text)

\section{INTRODUCTION}

Normal canine serum contains a complex of active substances (known collectively as complement) which can be detected in vitro by the use of the conventional or standard haemolytic indicator (a suspension of sheep-blood red cells sensitized with haemolytic antiserum). Hegedus \& Greiner (1938) found that, as with guineapig complement, canine complement consisted of four components. There is, however, but little information as to the specific activity of canine complement.

This laboratory has for the last 7 years been investigating canine viruses, during which period we have been mainly interested in studying the complementfixation reaction in the sera of dogs infected with these viruses and particularly the anti-complementary action to guinea-pig complement observed with many of these sera. While the causes of anti-complementary activity may be manifold, the experimental evidence, recently presented by Wiggin (1955), suggested that the anti-complementary action of inactivated and uncontaminated serum depends upon the relationship of $\alpha / \beta$ globulin ratio in the serum being tested, and also in the serum being used as a source of complement. It was thought that if Wiggin's concept was correct, then it would be reasonable to expect fewer examples of anti-complementary action with canine complement than with guineapig complement. The present communication is concerned with an examination of the suitability of canine complement for testing canine sera with virus antigen by the complement-fixation reaction, and also with a study of some of the conditions under which this reaction could be performed. The lack of information on the activity of canine complement made it necessary in the first place to compare the complement activity of canine and guinea-pig serum, and the results of these experiments are described in this paper.

\section{MATERIALS AND METHODS}

The basic methods of collecting, storing and standardizing materials throughout these experiments were those described in previous papers (Larin, 1951 $a, b$ and Larin \& Orbell, 1956).

\section{Standard diluent}

The standard diluent $\mathrm{Ca}-\mathrm{Mg}$ saline, buffered with veronal, was prepared in accordance with Wallace, Osler \& Mayer (1950); the autoclaved sterile solution had a $\mathrm{pH}$ of $7 \cdot 25-7 \cdot 30$. 


\section{Nomenclature}

In accordance with Pillemer \& Ecker (1941) complement is designated $C^{\prime}$ and its four recognized components are given the symbols $C^{\prime} 1, C^{\prime} 2, C^{\prime} 3$ and $C^{\prime} 4$. Abbreviations used for the complement in different animal sera are $c n \mathrm{C}^{\prime}$ for canine and $g p \mathrm{C}^{\prime}$ for guinea-pig complements.

Preparation of $c n \mathrm{C}^{\prime}$ and $g p \mathrm{C}^{\prime}$

Blood was chilled as soon as drawn, the serum was separated within $6 \mathrm{hr}$. and centrifuged at 3000 r.p.m. for $20 \mathrm{~min}$. The complements were used fresh or frozen, stored in sealed ampoules at $-40^{\circ} \mathrm{C}$.

\section{Inactivation of $\mathrm{C}^{\prime} 3$ and $\mathrm{C}^{\prime} 4$}

$\mathrm{C}^{\prime} 3$ was inactivated by treatment with zymosan (Ecker, Pillemer \& Seifter, 1943). $\mathrm{C}^{\prime} 4$ was inactivated by adding to serum $0 \cdot 15 \mathrm{~N} \mathrm{NH}_{4} \mathrm{OH}$. The mixture was incubated for $1 \mathrm{hr}$. at $37^{\circ} \mathrm{C}$. and neutralized with $0.15 \mathrm{~N} \mathrm{HCl}$.

Choice of the amount of the reagents used for $\mathrm{C}^{\prime} 3$ or $\mathrm{C}^{\prime} 4$ inactivation was based on actual tests for completeness of the inactivation with minimal destruction of the other components.

\section{The haemolytic indicator}

Sheep blood was collected in modified Alsever's solution (Bukantz, Rein \& Kent, 1946) and filtered through cotton wool; 2 mega units of crystalline penicillin ' $\mathrm{G}$ ' and $25 \mathrm{ml}$. of $0.15 \mathrm{M}$ solution of disodium ethylenediamine tetra-acetic acid (EDTA) made in $0 \cdot 14 \mathrm{M}$ solution of $\mathrm{NaOH}$, were added as preservatives to $500 \mathrm{ml}$. of filtered blood. (Pennell, 1953). The cells were thoroughly washed before use.

The haemolytic indicator consisted of $3 \%$ sheep blood cells sensitized with 5 MHD of commercial haemolytic amboceptor (horse serum).

\section{Complement-fixation reaction}

The method of performing the test was fundamentally that described in a previous paper (Larin \& Orbell, 1956). In brief, the scheme of reaction mixtures in test tubes was as follows:

\begin{tabular}{ll} 
Serum dilution & $0.5 \mathrm{ml}$. \\
Complement dilution & $0.5 \mathrm{ml}$. \\
Antigen dilution & $0.5 \mathrm{ml}$. \\
\multicolumn{1}{c}{ Total volume } & $\mathbf{1 . 5 \mathrm { ml } .}$
\end{tabular}

Where any component was omitted, enough standard diluent was always added to make the total volume $1.5 \mathrm{ml}$. Each reaction mixture was given primary incubation in a water bath at $37^{\circ} \mathrm{C}$. for $30 \mathrm{~min}$. Then $0.5 \mathrm{ml}$. of haemolytic indicator was added. This was followed by a final incubation in water bath at $37^{\circ} \mathrm{C}$. for $30 \mathrm{~min}$. Values representing $10,20,30,40,50,60,70,80,90$ and $100 \%$ lysis were read by eye with the use of standards. 


\section{Paper electrophoresis}

The electrophoresis equipment was X 118 'EEL' (Evans Electroselenium Ltd.). The buffer solution was $30 \cdot 0 \mathrm{~g}$. sodium barbitone, $19 \cdot 5 \mathrm{~g}$. sodium acetate (hydrated) and $205.0 \mathrm{ml} . \mathrm{N} / 10 \mathrm{HCl}$. These were made up to $3 \mathrm{l}$. of distilled water. The electrophoresis experiments were carried out in two baths (total twelve strips) connected to one power unit (the maximum output $12 \mathrm{~mA} 400 \mathrm{~V}$ ), for $29 \mathrm{hr}$. at a current of $0.75 \mathrm{~mA}$ per strip. Paper strips were stained with $0.25 \%$ bromphenol-blue in $95 \%$ ethanol saturated with mercuric chloride. Quantitative evaluation of proteins on the paper was made by direct photometry of the strip.

\section{RESULTS}

\section{Haemolytic activity of $\mathrm{cn}^{\prime} \mathrm{C}^{\prime}$}

It was first considered necessary to measure the haemolytic activity of $c n \mathrm{C}^{\prime}$, comparing this with the haemolytic activity of $g p \mathrm{C}^{\prime}$. In Fig. 1 are given results of experiments concerned with haemolysis produced with either of the above complements. The curve describing the haemolytic activity of $c n \mathrm{C}^{\prime}$ represents the mean-titre value obtained for twenty-five fresh canine sera, each serum originating from a different dog. The curve describing the activity of $g p \mathrm{C}^{\prime}$ represents the mean-titre value which was obtained for one guinea-pig serum-pool in twentyfive tests.

It will be noted from Fig. 1 that, as with $g p \mathrm{C}^{\prime}$, the relation between the amount of $c n \mathrm{C}^{\prime}$ used and fraction of cells lysed follows a course described by a S-shaped curve, $c n \mathrm{C}^{\prime}$ being less haemolytically active than $g p \mathrm{C}^{\prime}$. It is also evident that complete haemolysis with $c n \mathrm{C}^{\prime}$ is approached only gradually; thus relatively large increases in complement are required to effect lysis of the last $20-30 \%$ cells. The curve representing the activity of $c n \mathrm{C}^{\prime}$ indicates also that, in the central part, the reaction is more sensitive to small changes in the amount of complement employed. Therefore, as with $g p \mathrm{C}^{\prime}$, the use of complete, or $100 \%$ lysis, as an end-point, does not afford as sensitive an index of the haemolytic activity of $c n \mathrm{C}^{\prime}$ as an end-point in the central part of the curve, for example, at the point of $50 \%$ lysis.

\section{Pro-complementary activity of canine serum to canine complement}

It can be seen from Fig. 1 that canine serum, while showing anti-complementary activity to $g p \mathrm{C}^{\prime}$, was at the same time pro-complementary to $c n \mathrm{C}^{\prime}$. The curves describing either the anti-complementary activity of canine serum to $g p \mathrm{C}^{\prime}$ or the pro-complementary activity to $c n \mathrm{C}^{\prime}$ represent mean values obtained after testing thirty canine sera. In order that the tests with the two complements could be properly compared, each serum was inactivated at $56^{\circ} \mathrm{C}$. for $30 \mathrm{~min}$., diluted up to $20 \%$ and divided into two aliquots, one being tested with $g p \mathrm{C}^{\prime}$ and the second with $c n \mathrm{C}^{\prime}$. The same batch of $g p \mathrm{C}^{\prime}$ or of $c n \mathrm{C}^{\prime}$ was used throughout all the tests, each serum aliquot being tested at least twice. Appropriate control experiments showed that neither of these serum aliquots haemolysed sheep red-cells without the presence of the haemolytic serum and of either complement; this excluded the pos- 
sibility of either a lytic substance or natural haemolysin accounting for the procomplementary activity of canine serum to $c n \mathrm{C}^{\prime}$.

In order to determine whether the presence of $\mathrm{C}^{\prime} 3$ or $\mathrm{C}^{\prime} 4$ was in any way responsible for the pro-complementary activity of canine serum which had been heated at $56^{\circ} \mathrm{C}$., each serum before heating was divided into two aliquots, one

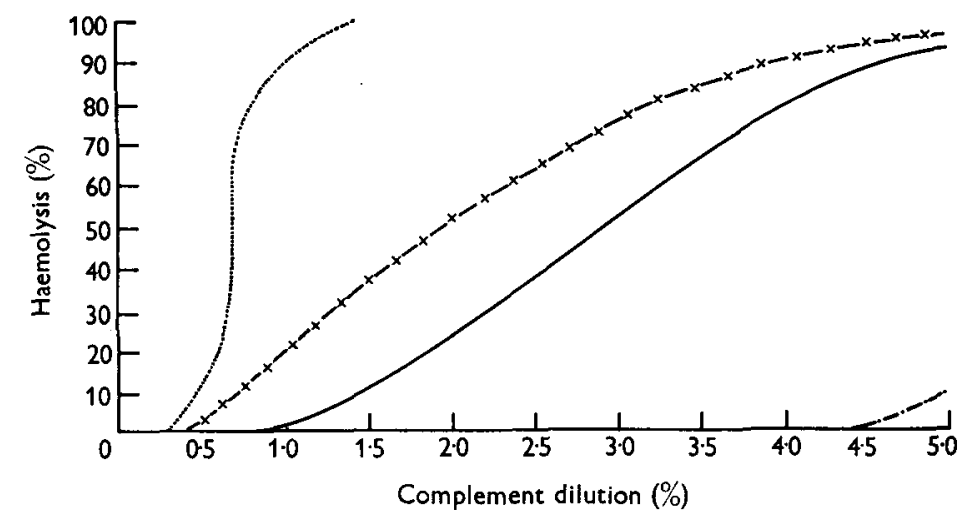

Fig. 1. The effect of the addition of heated (at $56^{\circ} \mathrm{C}$. for $30 \mathrm{~min}$.) canine serum anticomplementary to $g p \mathrm{C}^{\prime}$ on the degree of haemolysis observed with $c n \mathrm{C}^{\prime} . \cdot \cdots \cdot g p \mathrm{C}^{\prime} ;$ cn $\mathrm{C}^{\prime} ;-.-$, canine serum with $g p \mathrm{C}^{\prime} ;-\times-$, the same serum with $c n \mathrm{C}^{\prime}$.

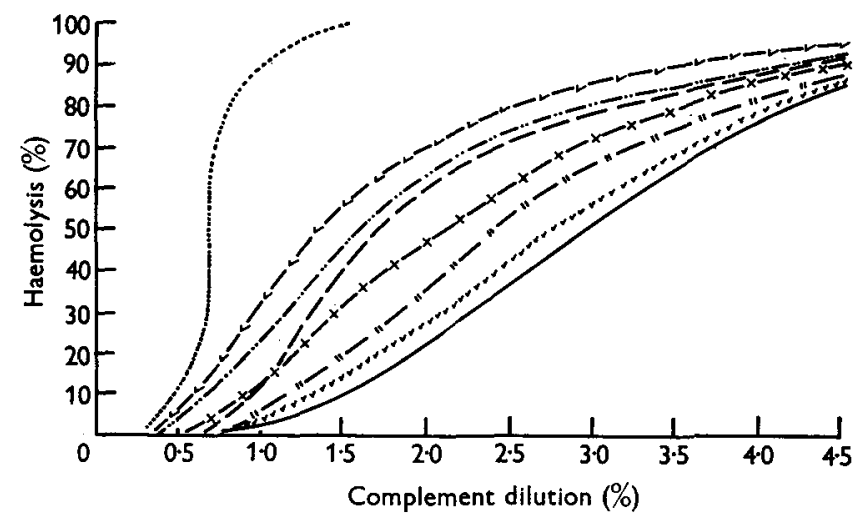

Fig. 2. The effect of different amounts of heated normal canine serum upon the amount of cn $\mathrm{C}^{\prime}$ which was required for $50 \%$ haemolysis, the haemolytic activity of $c n \mathbf{C}^{\prime}$ being compared with $g p \mathrm{C}^{\prime} \ldots . ., g p \mathrm{C}^{\prime}$; ——_,$c n \mathrm{C}^{\prime}$; $c n \mathrm{C}^{\prime}$ with canine serum : $\checkmark \checkmark \checkmark \checkmark, 1 \%$; - $\|, 5 \%$; $-\times-, 10 \% ;-\checkmark-, 20 \% ;-. .-50 \% ;-\longrightarrow, 100 \%$.

being treated with zymosan and the second with $\mathrm{NH}_{4} \mathrm{OH}$, and the aliquots treated in either way were tested with $c n \mathrm{C}^{\prime}$. Although the zymosan or ammonia treatment completely inactivated $\mathrm{C}^{\prime} 3$ and $\mathrm{C}^{\prime} 4$, respectively, the treated sera remained procomplementary to $c n \mathrm{C}^{\prime}$.

As shown in Fig. 2, the pro-complementary activity of canine serum to $c n \mathrm{C}^{\prime}$ increased in accordance with the concentration of the serum up to $20 \%$; further increase in concentration of serum up to $50 \%$, or the use of undiluted serum, decreased the pro-complementary activity. 
During these experiments it was observed that the pro-complementary activity of canine serum to $c n \mathrm{C}^{\prime}$ was more marked if both the serum being tested and that used as complement were obtained from the same dog. Therefore, it was thought of interest to determine whether the origin of serum and complement from the same animal would considerably affect the haemolysis levels. For this experiment, thirty canine sera were inactivated at $56^{\circ} \mathrm{C}$. for $30 \mathrm{~min}$. and diluted up to $20 \%$. Each diluted serum was divided into two aliquots, one being tested with $c n \mathrm{C}^{\prime}$ in the same fresh serum and the second with a different $c n \mathrm{C}^{\prime}$. The curves in Fig. 3 describing the pro-complementary activity of canine serum to its own $\mathrm{C}^{\prime}$ or to a different $c n \mathrm{C}^{\prime}$ represent mean-titre values obtained after testing each serum at least twice.

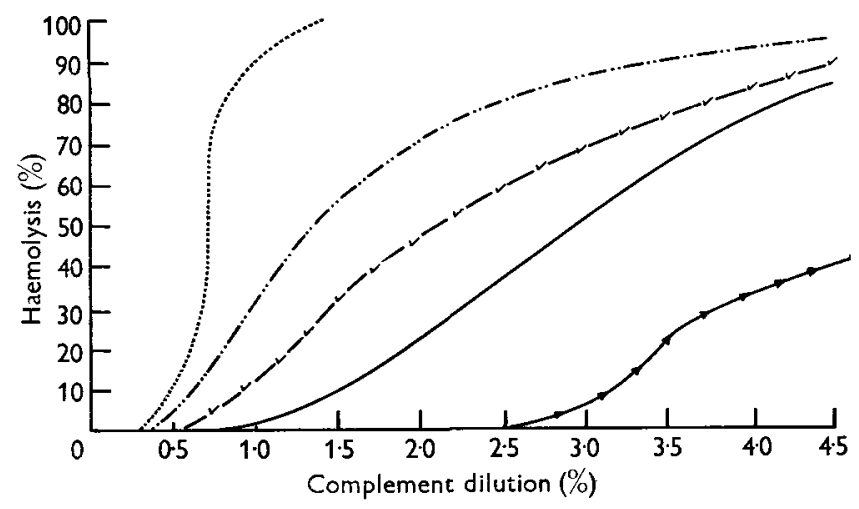

Fig. 3. The effect of heated normal canine serum (20\%) upon the amount of $c n \mathrm{C}^{\prime}$ which was required for $50 \%$ haemolysis, the haemolytic activity of $c n \mathrm{C}^{\prime}$ being compared with $g p \mathrm{C}^{\prime}$. . . . ., gp $\mathrm{C}^{\prime} ;-, c n \mathrm{C}^{\prime} ;-\ldots-$, canine serum with its own $\mathrm{C}^{\prime} ;-\sqrt{ }-$, canine serum with a different $c n \mathrm{C}^{\prime}$ (both serum aliquots were inactivated at $56^{\circ} \mathrm{C}$. for $30 \mathrm{~min}$.). $\rightarrow \rightarrow$, inactivated (at $62^{\circ} \mathrm{C}$.) canine serum with its own complement.

As shown in Fig. 3 the levels of pro-complementary activity of canine serum were higher if both the serum being tested and that used as complement were obtained from the same dog. In order to examine this point in relation to sera from different animal species, experiments were carried out to determine the pro-complementary activity to $c n \mathrm{C}^{\prime}$, if any, of human, bovine, rabbit and guinea-pig sera. The results of these experiments, given in Fig. 4, showed that heated sera from the above species were less pro-complementary to $c n \mathrm{C}^{\prime}$ than canine serum.

\section{Possible mechanism of the pro-complementary activity of canine serum}

In seeking an explanation for the pro-complementary activity of heated canine serum to $c n \mathrm{C}^{\prime}$, it was found that serum aliquots were either pro-complementary or anti-complementary, depending on whether inactivation temperature was 56 or $62^{\circ} \mathrm{C}$., respectively (see Fig. 3). The association of the pro-complementary or the anti-complementary serum activity with temperature of inactivation was of interest.in several respects. First, in our experiments both the serum being tested and the serum used as a source of complement originated from the same 
animal species. Therefore, if the concept that the anti-complementary activity of serum depended on the relationship between the $\alpha / \beta$ globulin ratio in the serum being tested and that in the serum being used as a source of complement (Wiggin, 1955), was correct, then it was likely that heating of the test serum either at 56 or $62^{\circ} \mathrm{C}$. would differently affect this ratio, and thus it was possible that both the anti-complementary and the pro-complementary serum activity was perhaps due to some physico-chemical alterations of the protein particle occurring after heating.

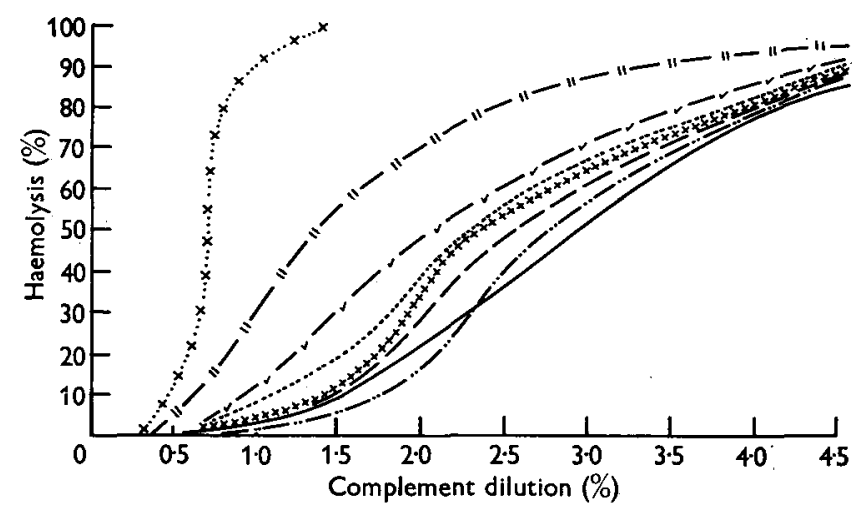

Fig. 4. The effect of heated sera $(20 \%)$ from different species upon the amount of $c n \mathrm{C}^{\prime}$ which was required for $50 \%$ haemolysis, the haemolytic activity of $c n \mathrm{C}^{\prime}$ being compared with $g p \mathrm{C}^{\prime}$. $\times \cdots \times, g p \mathrm{C}^{\prime} ;-, c n \mathrm{C}^{\prime} ;-\|$, canine serum with its own $\mathrm{C}^{\prime} ;-\sqrt{-}$, canine serum with a different $c n \mathrm{C}^{\prime} ;-\ldots-$, human serum with $c n \mathrm{C}^{\prime} ;---$, rabbit serum with $e n \mathrm{C}^{\prime} ; \times \times \times$, guineapig serum with $e n \mathrm{C}^{\prime} ; \ldots \ldots$, bovine serum with $c n \mathrm{C}^{\prime}$.

Finally, if one aliquot of serum heated at $56^{\circ} \mathrm{C}$. showed a pro-complementary effect, and the other aliquot, heated at $62^{\circ} \mathrm{C}$., showed an anti-complementary effect to $c n \mathrm{C}^{\prime}$ (the latter was in many of these tests an unheated aliquot of the same serum), then it would appear that the higher temperature had been responsible for a change in the pattern of protein distribution, and that this change might be related to the electric charge on the protein particle. To test this the following experiments were made.

Fresh haemoglobin-free sera obtained from healthy adult dogs were clarified by centrifugation at 3000 r.p.m. and pooled. Fresh or heated (at either 56,62 or $65^{\circ} \mathrm{C}$.) aliquots of the serum pool were applied in $0.01 \mathrm{ml}$. amount to Whatman no. 1 filter paper strips for electrophoretic separation of the protein.

The curves in Fig. 5 show that the protein particles in sera which have been heated at $56^{\circ} \mathrm{C}$. for $30 \mathrm{~min}$., migrated on the paper strips faster than the particles in unheated serum. On the other hand, the electro-migration was hindered considerably if serum was heated at 62 or $65^{\circ} \mathrm{C}$. for $30 \mathrm{~min}$. Here the protein, being adsorbed to the paper, formed patterns which were entirely different from those obtained with either unheated serum or that which had been heated at $56^{\circ} \mathrm{C}$. As shown in Fig. 6 the protein denaturation was more marked in serum aliquots which were heated at 62 or $65^{\circ} \mathrm{C}$. for $1 \mathrm{hr}$. The zymosan or ammonia treatment 
affected also the protein distribution (Fig. 7), the patterns, however, being less denatured than in heated sera (Figs. 5, 6). It can also be seen in Fig. 7 that the levels of optical density, representing concentrations of different protein fractions

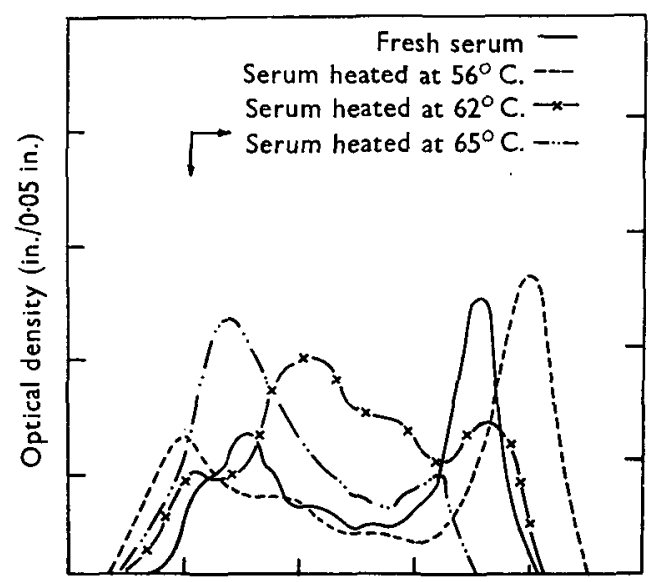

Fig. 5

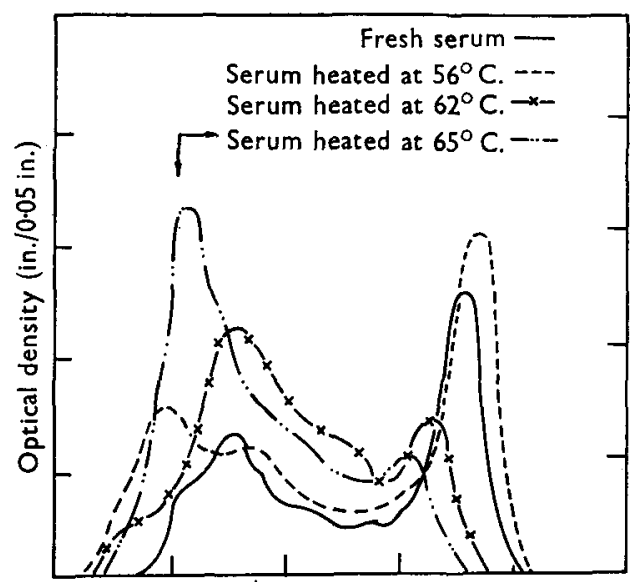

Fig. 6

Fig. 5. Paper electrophoresis of either fresh or heated (for $30 \mathrm{~min}$.) canine serum at different temperatures. Arrows indicate site of application and direction of run.

Fig. 6. Paper electrophoresis of either fresh or heated (for $1 \mathrm{hr}$.) canine serum at different temperatures. Arrows indicate site of application and direction of run.

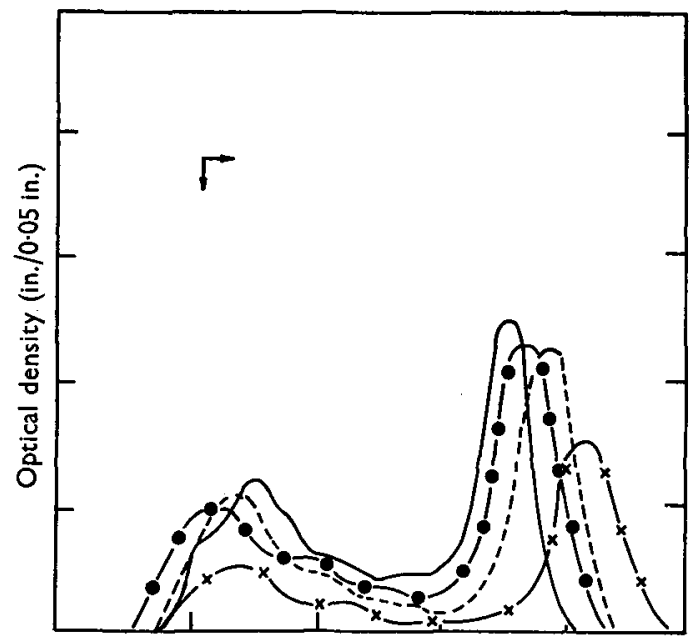

Fig. 7. Paper electrophoresis of four aliquots of canine serum-pool: $(a)$ fresh; $(b)$ -.- - , heated at $37^{\circ} \mathrm{C}$. for $\mathrm{I} \mathrm{hr.;}(c)-\times —$, treated with zymosan and $(d)-\ldots$, treated with $\mathrm{NH}_{4} \mathrm{OH}$. Arrows indicate site of application and direction of run.

in zymosan-treated serum aliquots, were somewhat lower if compared with untreated aliquots. Whether this phenomenon was caused by adsorption of serum protein to zymosan particles or whether the treatment with zymosan reduced the power of the serum protein to adsorb the dye, remains to be investigated. 
The experiments suggest that protein distribution was affected by heating serum at a temperature either of 56 or $62^{\circ} \mathrm{C}$, these being commonly used to inactivate serum for the complement-fixation reaction (Kolmer, Spaulding \& Robinson, 1952). Electrophoresis showed that heating also produced marked alterations in the serum proteins and the change from pro-complementary to anti-complementary action probably depended on this. While heating of serum aliquots either at 56 or $62^{\circ} \mathrm{C}$. affected differently the protein distribution (Figs. 5, 6), it also made the serum aliquots either pro-complementary or anti-complementary to $c n \mathrm{C}^{\prime}$ (Fig. 3).

\section{Complement-fixation reaction in virus system with the use of canine complement}

A typical protocol of testing canine serum with virus antigen by the use of either $g p \mathrm{C}^{\prime}$ or $c n \mathrm{C}^{\prime}$ is recorded in Fig. 8. This shows a degree of specific fixation of either complement to antigen-antibody complex consisting of canine hepatitis virus antigen, in the dilution of $1: 25$, and of positive canine serum, in the $20 \%$

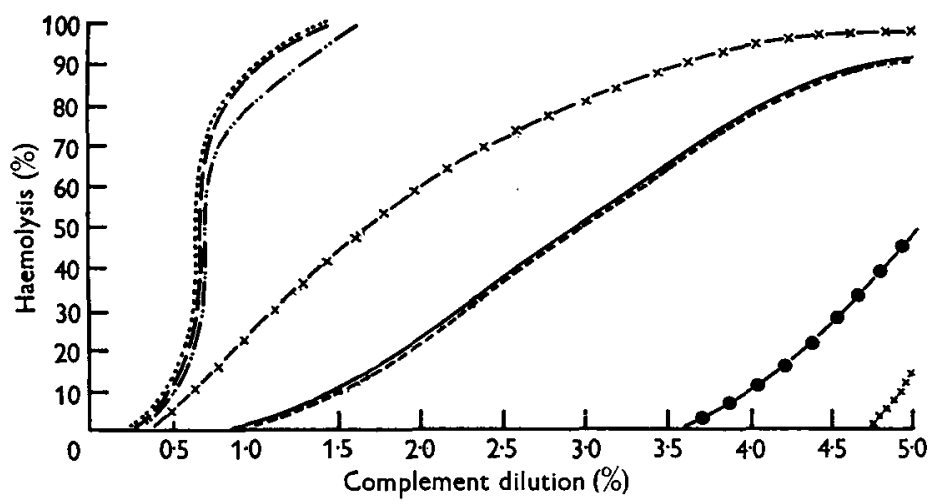

Fig. 8. Complement-fixing activity of canine hepatitis virus antigen (1:25 dilution) with standard antiserum (1:5 dilution) in the presence of varying amounts of $g p \mathrm{C}^{\prime}$ or $c n \mathrm{C}^{\prime}$. (1) $g p \mathrm{C}^{\prime}: \ldots$, , complement control; - - , antigen control; -..-, antiserum control; - - complement-fixing activity of antiserum with virus antigen. (2) $c n \mathrm{C}^{\prime}$ control; - - antigen control; - $\times-$, antiserum control; $\times \times \times$, complement-fixing activity of antiserum with virus antigen.

dilution, the serum being inactivated at $56^{\circ} \mathrm{C}$. for $30 \mathrm{~min}$. Considered as a whole, Fig. 8 shows $(a)$ that the virus antigen was not anti-complementary to either complement, $(b)$ that while positive canine antiserum was neither pro-complementary or anti-complementary to $g p \mathrm{C}^{\prime}$, it markedly enhanced the haemolytic activity of $c n \mathrm{C}^{\prime}$, and $(c)$ that the specific reaction of antigen-antibody complex with $c n \mathrm{C}^{\prime}$ was well marked, the degree of fixation being in all essentials comparable with that where $g p \mathrm{C}^{\prime}$ was used.

Another example of the complement-fixation reaction in virus systems with the use of $g p \mathrm{C}^{\prime}$ and $c n \mathrm{C}^{\prime}$ is shown in Fig. 9. Here positive canine antiserum was anti-complementary to $g p \mathrm{C}^{\prime}$, and hence the specific antigen-antibody reaction with the use of $g p \mathrm{C}^{\prime}$ could not be read. At the same time this serum was pro-complementary to $c n \mathrm{C}^{\prime}$ and hence the specific reaction of antigen-antibody complex 
with $c n \mathrm{C}^{\prime}$ could be assessed. We have not attempted in this investigation to estimate fixed $\mathrm{H}_{50}$ units of either complement. Individual canine sera can vary in the pro-complementary activity to the same batch of $c n \mathrm{C}^{\prime}$ and they can also have different antibody titres. A combination of the two variables may considerably complicate calculations of $\mathrm{H}_{50}$ units of the same batch of $c n \mathrm{C}^{\prime}$ used for the complement-fixation reaction with different canine sera.

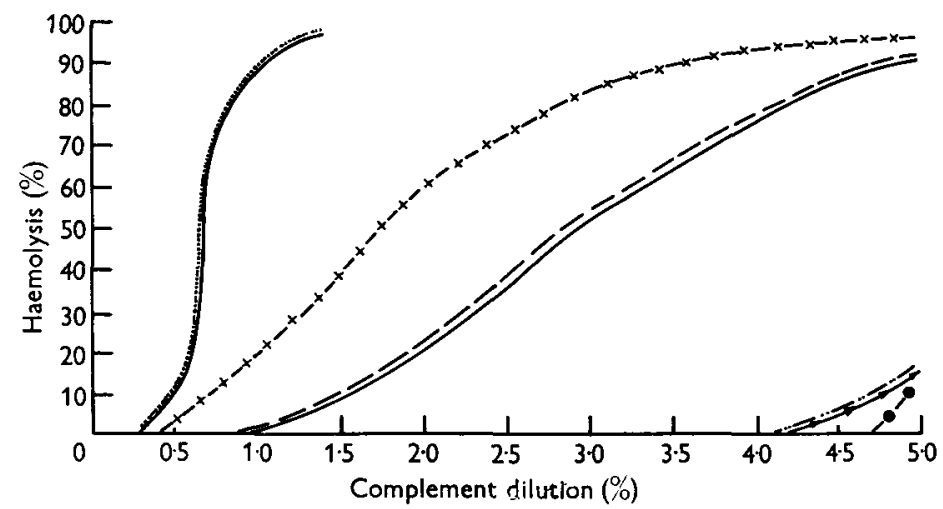

Fig. 9. Complement-fixing activity of canine hepatitis virus antigen (1:25 dilution) with anti-complementary antiserum (1:5 dilution) in the presence of varying amounts of $g p \mathrm{C}^{\prime}$ or $c n \mathrm{C}^{\prime}$. (1) gp $\mathrm{C}^{\prime}:$. . . , complement control; ——, antigen control ; -..一, antiserum control; $\rightarrow$ complement-fixing activity of antiserum with virus antigen. (2) $c n \mathrm{C}^{\prime}:---$, complement control; —_, antigen control; - $-x_{-}$, antiserum control; - - - complement-fixing activity of antiserum with virus antigen.

\section{DISCUSSION}

During an examination of the value of $c n \mathrm{C}^{\prime}$ as a substitute for $g p \mathrm{C}^{\prime}$, in testing canine sera with virus antigen by the complement-fixation reaction, some possible explanations for the pro-complementary and anti-complementary effect of canine serum to $c n \mathrm{C}^{\prime}$ become evident.

Under the experimental conditions employed, $c n \mathrm{C}^{\prime}$ was less active than $g p \mathrm{C}^{\prime}$. On the other hand, it is well known that complements exhibit considerable variations in their behaviour in vitro with the erythrocytes of different species, or with the same erythrocytes sensitized with the haemolytic serum prepared in different animals. This literature has recently been reviewed by Rice \& Boulanger (1952).

The ability of canine serum heated at $56^{\circ} \mathrm{C}$. to enhance the haemolytic activity of $c n \mathrm{C}^{\prime}$ has been well documented by the results of quantitative experiments. The mechanism of this enhancing action is little understood both with regard to the haemolytic activity of complement and also the role of the serum protein in the complement activity. Nevertheless, the data presented in this paper provide some insight into the conditions necessary for heated canine serum to bring about a significant enhancing effect on the haemolytic activity of $c n \mathrm{C}^{\prime}$.

As the concentration of heated serum $\left(56^{\circ} \mathrm{C}\right.$.) in serum dilutions is increased (up to $20 \%$ ), the haemolytic activity of $c n \mathrm{C}^{\prime}$ is enhanced. Further concentration (up to $50 \%$ or the use of undiluted serum) is less effective than the $20 \%$ serum. 
dilution. Thus the enhancing action of heated serum appears to be dependent on an optimal serum concentration (see Fig. 2).

When the test serum and that used as complement are obtained from the same dog, a higher haemolytic activity of $c n \mathrm{C}^{\prime}$ is observed (Fig. 3). It can be concluded from this and the evidence obtained in experiments with the use of heated sera from species other than the dog (Fig. 4), that the closer the relation between the protein pattern in the test serum and in that used as complement, the greater the enhancing effect of heated canine serum $\left(56^{\circ} \mathrm{C}\right.$.).

Canine serum enhanced the haemolytic activity of $c n \mathrm{C}^{\prime}(a)$ after inactivation at $56^{\circ} \mathrm{C}$. for $30 \mathrm{~min}$. (b) after zymosan treatment and subsequent heat inactivation, and $(c)$ after the $\mathrm{NH}_{4} \mathrm{OH}$ treatment and subsequent heat inactivation. Hence, it would seem that the activity of any of the four recognized complement components in the test serum is not itself concerned with this effect.

Wiggin (1955) has provided evidence that a certain relationship between the $\alpha / \beta$ globulin ratio in the test serum and that in the serum being used as a source of complement (the sera being obtained from different species) can be responsible for the anti-complementary activity of serum. In our experiments both the test serum and that used as a source of complement were obtained from one animal species, the dog, and in many experiments from the same animal, and both unheated serum and complement had either a very similar or identical pattern of the protein distribution when examined by paper electrophoresis. Fig. 3 shows that while a serum aliquot heated at $56^{\circ} \mathrm{C}$. was pro-complementary, the second aliquot, heated at $62^{\circ} \mathrm{C}$., was anti-complementary to the same batch of $c n \mathrm{C}^{\prime}$, and paper electrophoresis experiments showed that the above serum aliquots had different patterns of the protein distribution (Figs. 5, 6).

Before suggesting a possible causative relationship between the change of the protein pattern after heating canine serum either at $56^{\circ}$ C. or at $62^{\circ} \mathrm{C}$. (Figs. 5, 6), and the pro-complementary or anti-complementary serum activity, it is desirable to consider other possible explanations for the pro-complementary activity of heated canine serum $\left(56^{\circ} \mathrm{C}\right.$.) to canine complement.

The presence in the heated serum of a lytic substance or normal haemolysin can be ruled out, because neither canine serum used in these experiments haemolysed sheep erythrocytes without the presence of haemolytic serum and complement. Moreover, all these sera were pro-complementary to $c n \mathrm{C}^{\prime}$ and not to $g p \mathrm{C}^{\prime}$. A possibility that normal haemolysin in canine serum can fix only canine complement need not be considered, because a mixture of heated canine serum and $c n \mathrm{C}^{\prime}$ did not haemolyse sheep erythrocytes without the presence of haemolytic serum.

The fact that the inactivation of $\mathrm{C}^{\prime} 3$ and $\mathrm{C}^{\prime} 4$ with zymosan and ammonia respectively did not remove the pro-complementary activity would seem to exclude the possibility that either $\mathrm{C}^{\prime} 3$ or $\mathrm{C}^{\prime} 4$ was responsible for this effect. Paper electrophoresis studies showed that zymosan- or ammonia-treated sera had patterns of protein distribution which differed from those obtained with unheated sera. On the other hand, the protein patterns were less affected by this treatment than by heating (Figs. 5-7). 
In our experiments with paper electrophoresis there was a correlation between values of electro-migration and adsorption of the protein in heated serum aliquots and the latter's pro-complementary or anti-complementary activity to the same batch of $c n \mathrm{C}^{\prime}$. Hence, it is possible that the electric charge on the protein particle was responsible for either activity of serum aliquots. However, the assessment of changes in the protein electro-migration and adsorption in serum after heating, is not yet sufficiently complete to make a more specific identification.

Finally, this work has demonstrated that virus antigen-antibody complex reacted specifically with canine complement (Fig. 8), and thus it would seem that $c n \mathrm{C}^{\prime}$ can be used instead of $g p \mathrm{C}^{\prime}$ for testing canine sera by the complementfixation reaction, and most suitably replace it with advantage with test sera which are anti-complementary to $g p \mathrm{C}^{\prime}$ (Fig. 9).

\section{SUMMARY}

Quantitative studies have shown that the haemolytic activity of canine complement was in all essentials similar to guinea-pig complement. Canine serum which had been heated at $56^{\circ} \mathrm{C}$. markedly enhanced the haemolytic activity of canine complement. The complement-enhancing power of heated canine serum was found to be increased with the concentration of serum up to $20 \%$. Further concentration up to $50 \%$ serum dilution, or the use of undiluted serum, resulted in a reduction of this effect.

Serum aliquots were either pro-complementary or anti-complementary to $c n \mathrm{C}^{\prime}$, depending on whether they were heated at 56 or $62^{\circ} \mathrm{C}$.

Factors that possibly affect the complement-enhancement were investigated and evidence is presented which indicates that the electric charge on the protein particle is probably responsible for either the pro-complementary or anti-complementary serum activity; the mechanism of this, however, still remains obscure.

The present work shows also that canine complement can be used instead of guinea-pig complement for testing canine sera with virus antigen by the complement-fixation reaction, an advantage of this being that the use of canine complement permits the testing of canine sera which are anti-complementary to guinea-pig complement.

The data obtained are discussed in relation to canine complement and its specific activity.

The authors are indebted to Professor W. I. B. Beveridge for his constructive advice, to Dr R. R. A. Coombs for his helpful comments on the complement activity, and to Dr Christine E. Rice of the Animal Diseases Research Institute, Canada, who has generously supplied the zymosan.

Miss W. Barr and Miss M. Baker gave fine technical assistance throughout all the experiments. Miss M. Lambourne assisted in preparing the manuscript and graphs. 


\section{REFERENCES}

Bukantz, S. C., Rein, C. R. \& Kent, J. F. (1946). J. Lab. clin. Med. 31, 394.

Ecker, E. E., Pillemer, L. \& Seifter, S. (1943). J. Immunol. 47, 181.

Hegedus, A. \& Greiner, H. (1938). Z. ImmunForsch. $92,1$.

Kolmer, J. A., Spaulding, E. H. \& Robinson, H. W. (1952). Approved Laboratory Technique, p. 846. London: Lewis and Co.

LARIN, N. M. (1951a). J. Hyg. Camb., 49, 410.

LARIN, N. M. (1951b). Nature, Lond., 168, 745.

LaRin, N. M. \& Orbell, W. G. (1956). J. Hyg., Camb., 54, 141.

Penneld, R. B. (1953). Blood Cells and Plasma Proteins, p. 222. New York: Academic Press. Pillemer, L. \& Ecker, E. E. (1941). Science, 94, 437.

RICE, C. E. \& BoUlanger, O. (1952). J. Immunol. 68, 197.

Wallace, A. L., Osler, A. A. \& MAYer, M. M. (1950). J. Immunol. 65, 661.

WrgGIN, N. J. B. (1955). Studies on conglutination with specific reference to complement, anticomplementary action and immuno-conglutinin. Ph.D. thesis, Department of Pathology, Cambridge University.

(MS. received for publication 16. XI. 56) 